\title{
Anal Squamous Cell Carcinoma
}

National Cancer Institute

\section{Source}

National Cancer Institute. Anal Squamous Cell Carcinoma. NCI Thesaurus. Code C9161.

A squamous cell carcinoma (SCC) arising from the anal canal or the anal margin (perianal skin). Human papillomavirus is detected in the majority of cases. Homosexual HIVpositive men have an increased risk of developing anal squamous cell carcinoma in comparison to the general male population. Symptoms include anal pruritus, discomfort when sitting, pain, change in bowel habit, and bleeding. The prognosis is generally better for anal marg in SCC than for anal canal SCC. 